\title{
Eläinjalostus tuottaa lisäarvoa Suomen sikatalouteen
}

\author{
Kyösti Pietola $^{1)}$ ja Marja-Liisa Sevón-Aimonen ${ }^{2)}$ \\ ${ }^{1)}$ MTT Taloustutkimus, PL 3,00411 Helsinki,kyosti.pietola@mtt.fi \\ ${ }^{2)}$ MTT Kotieläinjalostus, 31600 Jokioinen, marja-liisa.sevon-aimonen@mtt.fi
}

\section{Johdanto}

Investoinneissa entistä parempaan eläinainekseen ja sianjalostukseen nähdään runsaasti potentiaalia parantaa suomalaisen sikatalouden kilpailukykyä. Hyvällä eläinaineksella voidaan paitsi alentaa sianlihan tuotantokustannuksia niin myös parantaa lihan laatua, lisätä koko sikaketjun arvoa ja todennäköisesti myös pienentää sianlihan tuotannon aiheuttamaa ympäristökuormitusta. Koko sikasektorin kannalta katsottuna eläinjalostukselle on ominaista myös se, että vuosittain aikaansaatu eläinaineksen paraneminen jää sikapopulaatioon pysyväksi. Kerran saavutetut tulokset parantavat paitsi sianlihan tuottajien niin myös yhteiskunnan hyvinvointia tulevinakin vuosina. Eläinjalostuksella aikaansaadut hyödyt eivät ilmeisesti kuitenkaan ole riittävän hyvin sikatalousyrittäjien tiedossa tai ne valuvat nopeasti kuluttajille. Investoinnit hyvään eläinainekseen jäävätkin sen vuoksi alhaisemmiksi kuin olisi yhteiskunnan hyvinvoinnin kannalta optimaalista. Toisaalta hyvään eläinainekseen investoivilla tiloilla myös sikojen ruokintaa tulee tarkentaa eläinten kasvupotentiaalin mukaan, jotta päästään parhaimpaan taloudelliseen tulokseen.

Tässä tutkimuksessa rakennetaan sikojen kasvua kuvaava optimointimalli, joka ratkaistaan numeerisesti käyttäen dynaamista ohjelmointia (Bellman 1957, Burt 1993). Tavoitteena on selvittää millainen on perimältään ja jalostusarvoltaan hyvätasoisten sikojen optimaalinen ruokinta ja teurastuksen ajoitus. Toisena tavoitteena on estimoida sianjalostuksesta saadut hyödyt sikojen kasvattajan näkökulmasta. Jalostusarvoltaan erilaisten ( $\mathrm{K}$ indeksillä mitattuna) eläinten tuottoja vertaillaan niin, että ne kukin ruokitaan ja teurastetaan optimaalisesti ottaen huomioon eläimen kasvunopeus, rehun kysyntä ja ruhon arvo.

\section{Malli}

Lihasian kasvatusmenetelmän optimoinnissa tarvitaan ratkaisu kahteen ongelmaan: (1) sian ruokinta kussakin kasvuvaiheessa ja (2) teurastuksen ajoitus (esim. Kennedy 1986). Nämä kaksi optimointitehtävää vaikuttavat ratkaisevasti toisiinsa. Esimerkiksi optimaaliseen ruokintaan vaikuttaa se, kuinka teurastus tullaan ajoittamaan. Tässä tutkimuksessa nämä kaksi toisiinsa kytkettyä optimointitehtävää ratkaistaan sijoittamalla sian kasvua ja ruokintaa kuvaava yhden periodin malli dynaamiseen ohjelmointirutiiniin.

Mallissa jaetaan ruhon kasvu lihas- ja rasvakudokseen, joiden avulla saadaan paitsi ruhon paino niin myös sen laatukorjattu arvo (esim. Glen 1983). Vesi, tuhka ja sian elopaino lasketaan lihas- ja rasvakudosten määrän perusteella. Rehussa on kolme komponenttia: viljapohjainen energiarehu, soijapohjainen valkuaisrehu ja aminohappotäydennys. Mallissa on mukana sekä rajoitettu- että vapaa ruokinta. Vapaalla ruokinnalla eläin kasvaa oman kasvupotentiaalinsa mukaisesti ja käyttää tämän kasvunopeuden edellyttämän rehumäärän. Rajoitetussa ruokinnassa esimerkiksi energiaruokintaa rajoitetaan ruhon laadun parantamiseksi niin, että rasvakudoksen kasvu hidastuu.

Silloin kun sian kasvattamista päätetään jatkaa, sen kasvu kuvataan siirtymäyhtälöillä:

$$
x_{t+1}=x_{t}+f^{j}\left(x_{t}, u_{t}^{f}\right)
$$

missä vektori $x_{t}$ sisältää lihaskudoksen ja rasvakudoksen painon hetkellä $t, f^{j}\left(\right.$.) on kasvufunktio ja $u_{t}^{f}$ on ruokinta. Sekä lihas- että rasvakudokselle on määritetty kaksi eri siirtymäyhtälöä sen perusteella onko ruokinta vapaata vai rajoitettua. Vapaalla ruokinnalla j saa arvon yksi $(j=1)$ ja sian kasvu vastaa sen geneettistä kasvupotentiaalia. Rajoitetulla $(j=2)$ ruokinnalla kasvufunktio poikkeaa kasvupotentiaalia noudattavasta funktiosta. 
Jos sika päätetään teurastaa, sen tilalle otetaan uusi porsas ja siirtymäyhtälö on

$$
x_{t+1}=x_{0}
$$

missä $x_{0}$ on lihas- ja rasvakudosten paino 20 kiloisella välitysporsaalla.

Liittämällä yllä kuvattuihin yhden periodin kasvumalleihin rehujen kysyntä, rehujen hinnat, laatukorjatut lihan hinnat, porsaan hinta, siasta maksettavat tuet ja teurastushävikki saadaan yhden periodin tuottofunktio $\mathrm{R}($.$) . Yhden periodin tuotot linkitetään yhteen usean periodin optimointimallilla,$ joka noudattaa Bellmannin yhtälöä (Bellman 1957):

$$
V_{t}\left(x_{t}\right)=\max _{u^{s}, u^{f}}\left\{R_{t}\left(x_{t}, u_{t}^{s}, u_{t}^{f}\right)+\beta V_{t+1}\left(x_{t+1}\right)\right\} \quad \text { kun } t \in[0, T)
$$

niin että

$$
\begin{array}{lll}
x_{t+1}=x_{t}+f^{j}\left(x_{t}, u_{t}^{f}\right) & \text { jos } u_{t}^{s}=0 & \\
x_{t+1}=x_{0} & \text { jos } u_{t}^{s}=1 & \text { (jatketaan kasvatusta) }
\end{array}
$$

missä $V_{t}($.$) on optimaalinen arvofunktio, u_{t}^{s}$ on sian teurastuspäätöstä kuvaava muuttuja. Se saa arvon yksi kun sika teurastetaan ja arvon nolla kun kasvatusta päätetään jatkaa. $\beta$ on exogeeninen diskonttaustekijä ja $T$ on optimointijakson pituus. Koska Bellmannin yhtälö ratkaistaan numeerisesti, optimointijakson on oltava äärellinen. Optimointijakson lopussa eli hetkellä $t=T$ sika aina teurastetaan ja arvofunktio $\left(V_{T}\right)$ on yhtä suuri kuin sian teurasarvo. Optimointijakson pituutena käytettiin 700 päivää eli vajaata kahta vuotta.

\section{Tulokset ja johtopäätökset}

Tulosten mukaan malli rajoittaa energiaruokintaa ennen teurastusta. Valkuaisruokinta kasvaa nuorella porsaalla ensin nopeasti mutta alkaa sen jälkeen alentua (kuva 1). Optimaalinen aminohappotäydennys on vakio koko kasvatusajan ja se on 2 grammaa lysiiniä per viljakilo. Yhteenlasketussa rehuseoksessa (ohra plus soija) valkuaisen osuus alenee srv-prosentilla mitattuna lähes lineaarisesti pienen porsaan vaatimasta vajaasta 14 prosentista teuraskypsyyttä lähestyvän sian vaatimaan kahdeksaan prosenttiin (kuva 2).

Eläinainekseltaan hyvän sian optimaalinen teuraspaino on mallissa noin 115 kiloa. Hyvä sika kannattaa kasvattaa hieman raskaammaksi kuin heikko sika. Hyvän ja heikon eläinaineksen välinen ero on tutkimuksessa käytetyssä aineistossa $10 \mathrm{~K}$-indeksipistettä.

Yhdessä vuodessa sianjalostus etenee noin neljä K-indeksipistettä. Tällä nopeudella jalostus parantaa tulosten mukaan yhden sikapaikan vuosikatetta 10 markalla. Koska kerran aikaan saatu eläinaineksen parannus jää sikaketjuun pysyväksi, on sen nykyarvo viiden prosentin korkokannalla 200 markkaa. Jos sianlihan kysyntä säilyy vakaana niin, että Suomessa oleva noin 570000 sikapaikan kapasiteetti pysyy tuotannossa, on yhden vuoden jalostustyön arvo noin 114 miljoonaa markkaa. Eläinjalostuksesta aiheutuvia kustannuksia on vaikea tarkkaan arvioida, mutta ne jäävät laskentatavasta riippumatta selvästi tulosten osoittamia hyötyjä alhaisemmiksi (esim. Faban kustannus sianjalostukseen on noin 8,5 milj. mk vuodessa).

Tulokset osoittavat, että suomalaisilla sikatiloilla on potentiaalia parantaa kilpailukykyään investoimalla aikaisempaa enemmän hyvään eläinainekseen. Sianjalostuksella aikaansaatujen tulosten yhteiskunnalliset hyödyt ovat tulosten mukaan myös suuret. 

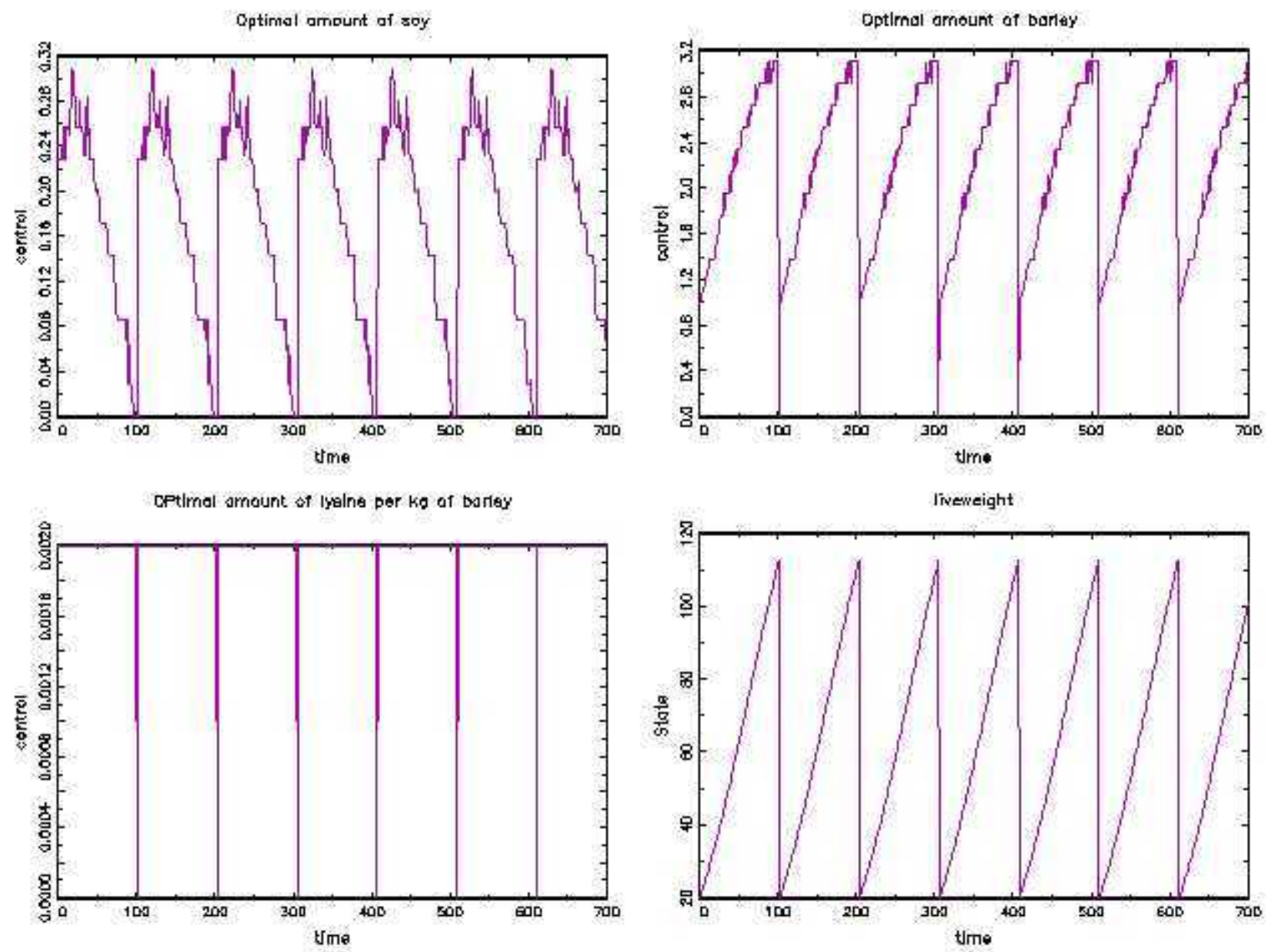

Kuva 1. Eläinainekseltaan hyvän sian optimaalinen soijaruokinta $\mathrm{kg} /$ päivä (vasen yläkuva), viljaruokinta $\mathrm{kg} /$ päivä (oikea yläkuva) ja lysiinitäydennys g/ohrakilo (vasen alakuva) ja elopainon kehitys teurastushetkineen (oikea alakuva).

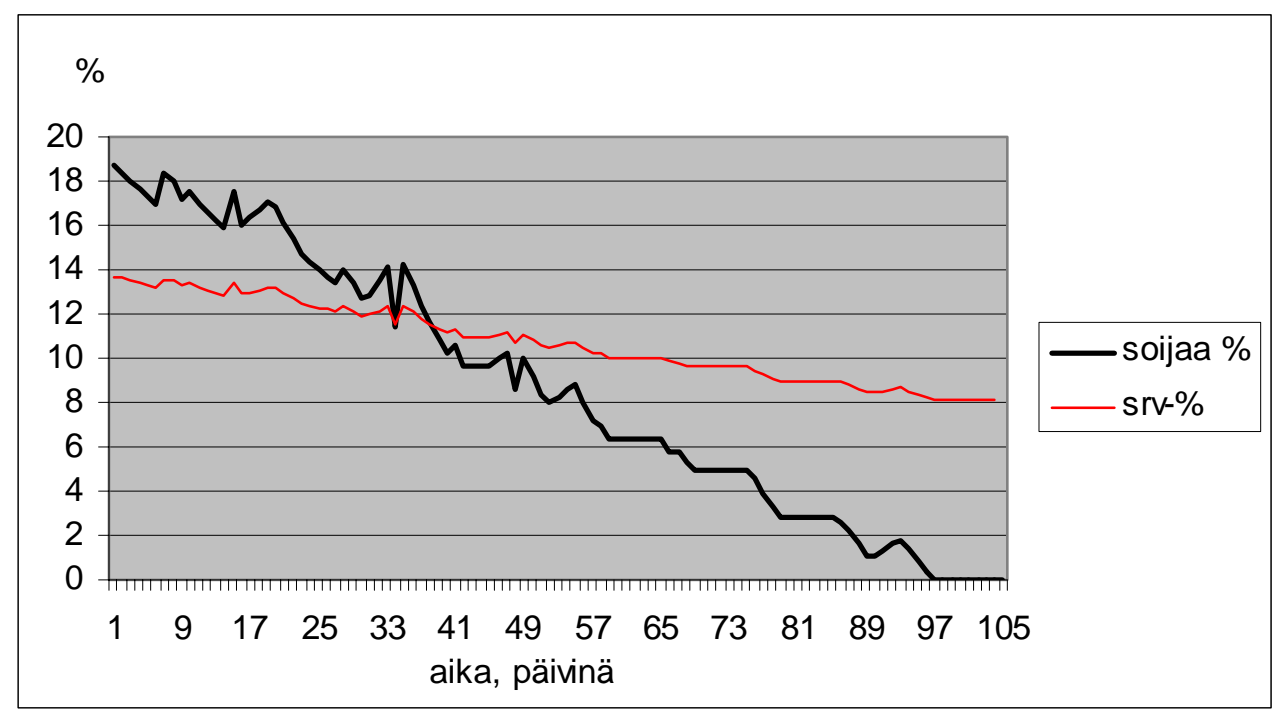

Kuva 2. Soijan osuus rehuseoksessa ja rehuseoksen sulava raakavalkuainen (srv \%). 


\section{Kirjallisuus}

Bellman, R. 1957. Dynamic Programming. New Jersey. 339 p.

Burt, O.R. 1993. Decision Rules for the Dynamic Animal Feeding Problem. Amer. J. Agr. Econ. 75(February): 190-202.

Glen, J.J. 1983. A Dynamic Programming Model for Pig Production. J. Operational Research Society Vol 34 6:511-519.

Kennedy, J.O.S. 1986. Livestock Management in Dynamic Programming: Applications to Agriculture and Natural Resources, Elsevier London, Chapter 7. 